Naohiko Seki • Akiko Hayashi • Atsushi Hattori

Sumie Kozuma • Miki Ohira • Tada-aki Hori

Toshiyuki Saito

\title{
Chromosomal assignment of a human apoptosis-associated tyrosine kinase gene on chromosome 17q25.3 by somatic hybrid analysis and fluorescence in situ hybridization
}

Received: August 27, 1998 / Accepted: October 21, 1998

\begin{abstract}
Here, we report on the chromosomal location of the human apoptosis-associated tyrosine kinase gene. Based on polymerase chain reaction analysis with a human/ rodent monochromosomal hybrid cell panel and fluorescence in situ hybridization, the gene was mapped on 25.3 region of chromosome 17 .
\end{abstract}

Key words Apoptosis-associated tyrosine kinase $\cdot$ Chromosome 17q25.3 · FISH · Hybrid cell panel

A novel tyrosine kinase (apoptosis-associated tyrosine kinase, AATYK) gene was isolated from the 32Dcl3 cell line, which was derived from normal mouse bone marrow (Gaozza et al. 1997). The cells were strictly dependent on interleukin 3 (IL-3) for growth, and apoptosis occurred when they were deprived of IL-3 (Greenberger et al. 1983; Rovera et al. 1987; Valtieri et al. 1987). The expression of the AATYK gene was dramatically up-regulated during IL3 deprivation as well as granulocyte colony-stimulating factor-induced terminal differentiation of the cells (Gaozza et al. 1997).

More recently, a human homolog of the AATYK gene has been reported (Ishikawa et al. 1998) and registered with the public database (accession number AB014541). This human gene and the mouse AATYK gene are $87 \%$ identical at the amino acid level, and both genes encode a protein with a tyrosine kinase domain in the $\mathrm{N}$-terminal region and a proline-rich domain at the $\mathrm{C}$-terminal end.

N. Seki · A. Hayashi $\cdot$ S. Kozuma $\cdot$ T. Hori · T. Saito $(\bowtie)$

Genome Research Group, National Institute of Radiological

Sciences, Anagawa 4-9-1, Inage-ku, Chiba 263-8555, Japan

Tel. +81-43-206-3135; Fax +81-43-251-9818

e-mail: t_saito@nirs.go.jp

M. Ohira

Division of Biochemistry, Chiba Cancer Center Research Institute, Chiba, Japan

\section{A. Hattori}

Genome Research Group, National Institute of Radiological

Sciences, Chiba, Japan, and Biotechnology and Medical Engineering

Field, Aisin Cosmos R\&D Co., Ltd., Tokyo, Japan
Precise investigation of the chromosomal location of the human AATYK gene is important to investigate the role of AATYK in diseases such as tumorigenesis. First, chromosomal assignment of human AATYK was undertaken by polymerase chain reaction (PCR) analysis of a human/ rodent somatic cell hybrid panel, as described previously (Saito et al. 1995, 1997; Seki et al. 1997). A set of specific PCR primers for human AATYK gene was designed in the $3^{\prime}$-untranslated region of the gene (5'-AGGCATGGCCCCGAGACACTG-3'; 5'-GATAAGGGCAGCGGAAACAGG-3', PCR product $138 \mathrm{bp})$. The specific amplified product using the primer set was detected only from the hybrid containing human chromosome 17 (data not shown). This observation accords with a previous report (Ishikawa et al. 1998). To determine the precise location of the gene by an independent approach, we then performed fluorescence in situ hybridization (FISH) using P1 phage DNA containing the gene. The $\mathrm{P} 1$ clone was isolated by the method as described previously (Ohira et al. 1997), using the same primers described above. Clear doublet signals were consistently demonstrated for the q25.3 position of chromosome 17. A typical pattern from the FISH experiment is shown in Fig. 1. Thus, the gene was judged to map on $17 \mathrm{q} 25.3$.

Chromosome 17 is one of the major chromosomes showing frequent deletions in human malignancies (Seizinger et al. 1991). In the Loss of Heterozygosity (LOH) studies, interstitial losses in the chromosome $17 \mathrm{q} 25$ region were observed in both breast and ovarian neoplasms, suggesting that one or more novel tumor suppressor genes might exist in this region (Kalikin et al. 1997). Our precise chromosomal positioning data for such a gene should contribute toward LOH studies and genetic linkage analysis of this genomic locus.

\section{References}

Gaozza E, Baker SJ, Vora RK, Reddy EP (1997) AATYK: a novel tyrosine kinase induced during growth arrest and apoptosis of my- 
Fig. 1 Chromosome mapping of the human AATYK gene. FISH of the AATYK gene on human partial chromosomes. FISH was carried out using a biotinylated hybridization probe made from P1 phage clone harboring the AATYK gene. Arrows indicate the hybridization signals on human chromosome 17q25.3. The metaphase spreads were photographed with a Nikon B-2A filter (Nikon, Tokyo, Japan)
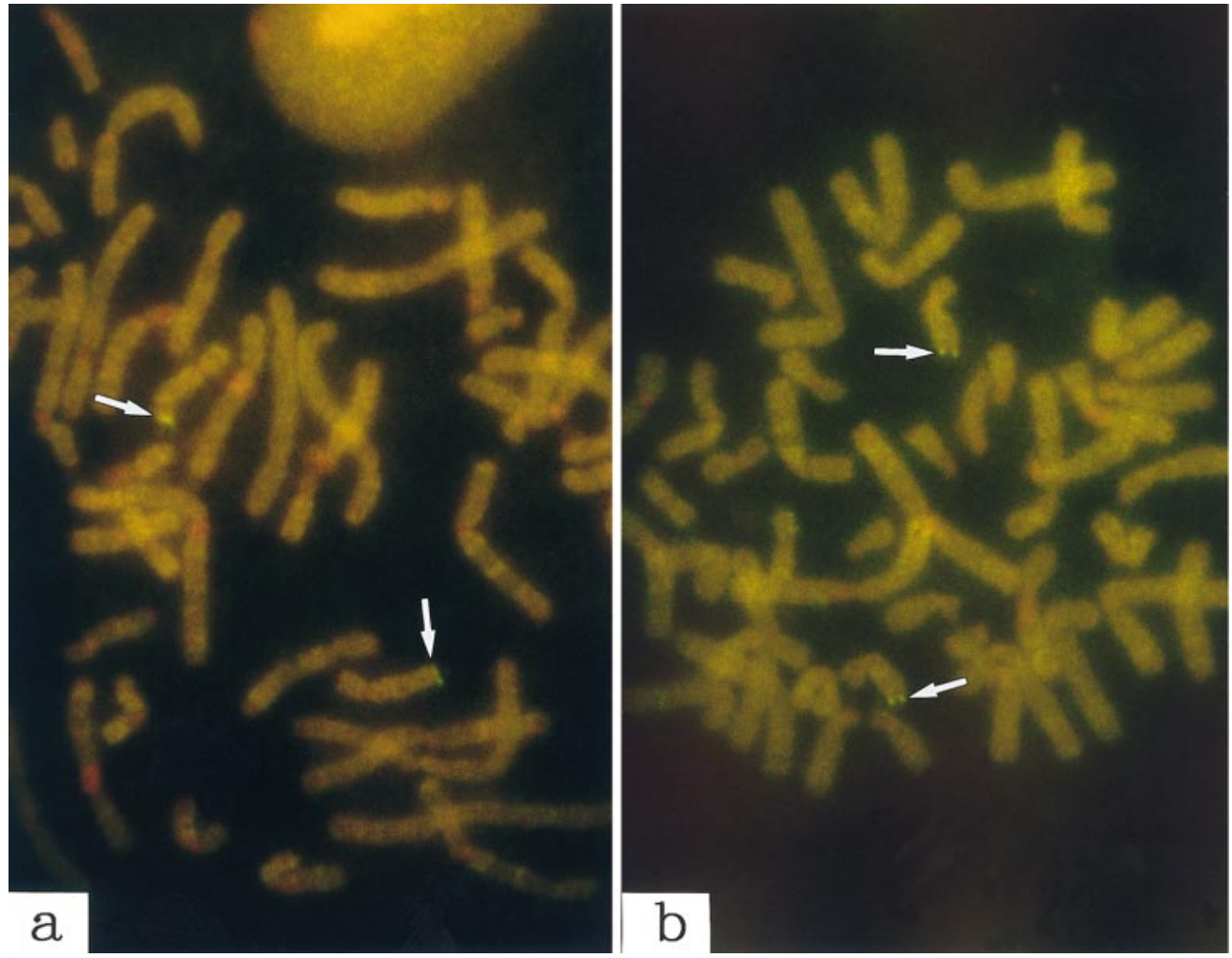

eloid cells. Oncogene 15: 3127-3135

Greenberger JS, Sakakeeny MA, Humphries RK, Eaves CJ, Eckner RJ (1983) Demonstration of permanent factor-dependent multipotential (erythroid/neutrophil/basophil) hematopoietic progenitor cell lines. Proc Natl Acad Sci USA 80: 2931-2935

Ishikawa K, Nagase T, Suyama M, Miyajima N, Tanaka A, Kotani H, Nomura N, Ohara O (1998) Prediction of the coding sequences of unidentified human genes. X. The complete sequences of 100 new cDNA clones from brain which can code for large proteins in vitro. DNA Res 5: 169-176

Kalikin LM, Frank TS, Svoboda-Newman SM, Wetzel JC, Cooney KA, Petty EM (1997) A region of interstitial 17q25 allelic loss in ovarian tumors coincides with a defined region of loss in breast tumors. Oncogene 14: 1991-1994

Ohira M, Seki N, Nagase T, Suzuki E, Nomura N, Ohara O, Hattori M, Sakaki Y, Eki T, Murakami Y, Saito T, Ichikawa H, Ohki M (1997) Gene identification in 1.6-Mb region of the Down syndrome region on chromosome 21. Genome Res 7: 47-58

Rovera G, Valtieri M, Mavilio F, Reddy EP (1987) Effect of Abelson murine leukemia virus on granulocytic differentiation and interleukin3 dependence of a murine progenitor cell line. Oncogene 1: 29-35
Saito T, Seki N, Matsuda Y. Kitahara M, Murata M, Kanda N, Nomura N, Yamamoto T, Hori T (1995) Identification of the human ERK gene as a putative receptor tyrosine kinase and its chromosomal localization to 1p36.1: a comparative mapping of human mouse, and rat chromosomes. Genomics 26: 382-384

Saito T, Seki N, Ishii H, Ohira M, Hayashi A, Kozuma S, Hori T (1997) Complementary DNA cloning and chromosomal mapping of a novel phosphatidylinositol kinase gene. DNA Res 4: 301-305

Seizinger BR, Klinger HP, Junien C, Nakamura Y, Le Beau M, Cavenee W, Emanuel B, Ponder B, Naylor S, Mitelman F, Louis D, Menon A, Newsham I, Decker J, Kaelbling M, Henry I, Deimling AV (1991) Report of the committee on chromosome and gene loss in human neoplasia. Cytogenet Cell Genet 58: 1080-1096

Seki N, Nimura Y, Ohira M, Saito T, Ichimiya S, Nomura N, Nakagawara A (1997) Identification and chromosome assignment of a human gene encoding a novel phosphatidylinositol-3 kinase. DNA Res 4: 355-358

Valtieri M, Tweardy DJ, Caracciolo D, Johnson K, Mavilio F, Altmann S, Santoli D, Rovera G (1987) Cytokine-dependent granulocytic differentiation. Regulation of proliferative and differentiative responses in a murine progenitor cell line. J Immunol 138: 3829-3835 